\title{
Fiscal Policy, Labour Productivity Growth and Convergence between Agriculture and Manufacturing: Implications for Poverty Reduction in Cameroon
}

\author{
Tabi Atemnkeng Johannes \\ Faculty of Economics and Management, University of Dschang \\ P. O. Box 110, Dschang, Cameroon \\ E-mail: jtabiatem@yahoo.com \\ Aloysius Mom Njong \\ Faculty of Economics and Management, University of Dschang \\ P. O. Box 110, Dschang, Cameroon \\ E-mail: mom_aloys@yahoo.fr
}

\begin{abstract}
Received: July 22, $2011 \quad$ Accepted: November 29, $2011 \quad$ Published: April 1, 2012
doi:10.5539/ass.v8n4p190 URL: http://dx.doi.org/10.5539/ass.v8n4p190
\end{abstract}

This is an updated version of a greater part of a research work carried out with the aid of a grant from the Global Development Network (GDN) in 2005, under the Research projects on macroeconomic Policy Challenges in Low income Countries.

\begin{abstract}
This paper examines the factors that drive labour productivity convergence between agriculture and manufacturing activities in Cameroon over 1969-2005. It is supposed that whenever one sector grows in terms of labour productivity it will also bring benefit to other industries. For instance, agriculture plays a significant role in reducing poverty. The bulk of the poor are engaged in agriculture and so an increase in agricultural productivity has a significant potential for reducing such poverty. Our findings indicate that while government spending on education, health, and road infrastructures promotes convergence, agricultural spending reinforces inequality in sectoral labour productivity by disproportionately increasing non-agricultural sector productivity. Furthermore, increases in manufacturing and service productivity levels both have a positive impact on agricultural productivity in the long-run, with manufacturing equally contributing in the short-run.
\end{abstract}

Keywords: Convergence, Labour productivity, Agriculture, Manufacturing, Poverty reduction

\section{Introduction}

Productivity growth appears to have become one of the surest routes to growth and poverty reduction. The literature provides strong evidence that growth reduces poverty (Dollar and Kraay, 2002; CSLS, 2003) and in dynamic economies most economic growth comes from productivity growth (Note 1). There are indications that productivity growth is important for poverty reduction and even appears stronger than the link between growth and poverty reduction (CSLS, 2003) (Note 2). This issue is important especially for African countries that have higher levels of poverty and inequality (World Bank, 1995) and in the light of the first United Nations Millennium Development Goal envisaging the reduction of developing world poverty by half over 1990-2015.

The most popular notion of productivity is that relating to labour and that compares production to the quantity of labour employed in the production process. In this paper, we examine the effect of public expenditure on sectoral labour productivity and also find out if there are spillover effects (i.e., diffusion of productivity or technology between sectors). In sub-Saharan Africa, labour productivity is low especially in agriculture compared to manufacturing. To this end, developing an understanding of the relationship between productivity growth in 
agriculture and manufacturing, and on the impact of policies on sectoral productivity convergence can provide insights to government policy action.

The Lewis (1954) theory of structural change is important here, where labour productivity growth and the intensive use of labour can occur either via reallocation of labour or spillovers in production techniques between sectors resulting to productivity convergence. However, convergence may take a long time to occur especially in a low-income, agriculture-based economy such as Cameroon, expected to be in the midst of the transformation process, far from full commercialisation of all labour markets. Based on Rostow's doctrine, this also involves a transition from underdevelopment to development which should pass through a series of stages and as a matter of time (Rostow 1958). This paper has determined that fiscal policy partly explains the convergence of agriculture and manufacturing productivity levels and much time is required for convergence to actually take place. The remainder of the paper is organised as follows. In the next section we present the economic situation of Cameroon, followed by methods and nature of data used and the empirical strategy adopted. The discussion of results follows with a summary of findings and policy implication.

\section{Overview of Cameroon economy}

Economic growth in Cameroon has been uneven during 1960-2007 both at the aggregate and the sectoral level. After gaining independence in 1960, the country experienced, first, a period of modest, but balanced economic growth, followed by an episode of growth acceleration over 1977-1985-averaging 7 per cent per year. This was driven mainly by the agricultural sector which employed more than 80 percent of the labour force and accounted for 32 percent of GDP. Agriculture was also a major contributor to export earnings through mainly cocoa and coffee (Benjamin and Devarajan, 1986). The manufacturing sector accounted for about 25 percent of GDP as the period was also characterized by early import substitution-based industrialization. Increased oil revenues were also a source of growth as Cameroon became an oil producer in the late 1970s. The peace dividend of the first period, combined with favourable exchange rates and other macroeconomic policies further stimulated this growth process.

However, after 1985, deteriorating terms of trade, a sharp decline in oil output, and a major appreciation of real exchange rates, exposed the structural weaknesses of the economy, and triggered a profound recession with repercussions on public finances. With the support of the Bretton Woods institutions, the country implemented several structural adjustment programs. Economic growth was reignited with exchange rate adjustments and the reform of trade and fiscal policy in 1994. Subsequent to the relative success in its macro-economic stabilisation effort, Cameroon registered an annual average growth of around 4.5 per cent during 1996-2001 despite the continuing decline of the oil sector. Over the same period, per capita income rose annually at about 2 per cent. By 2001, health, education indicators, and access to basic services were still alarmingly low, and in some cases worse than they were in the 1980s (Government of Cameroon, 2003). With the economic situation improving since the mid-1990s, government expenditures and budgetary revenues started increasing and social and infrastructure spending picked up (Table 1). The dramatic social consequences of the negative economic and financial situation experienced in the mid-80s were yet to be reversed by the structural adjustment policies (SAP).

Poverty alleviation became a major policy concern in Cameroon, as evidenced when the IMF-supported Enhanced Structural Adjustment Facility (ESAF) (schedule for 1997-2000) was converted to the Poverty Reduction and Growth Facility (PRGF) in 1999. Between 2000 and 2003, the government of Cameroon formulated a Poverty Reduction Strategy Paper (PRSP) which documented guidelines for fighting poverty (Note 3). The Government undertook to develop and implement a national employment policy integrated to the poverty reduction strategy. This policy aimed to promote income-generating activities, self-employment of the poor, the development of small and medium size enterprises and to support the initiatives of the poor in the growth sectors. Policies were designed to achieve and maintain a high rate of poverty-reducing economic growth. They involved maintaining macroeconomic stability, consolidating and deepening ongoing reforms to further liberalize and modernize the economy and improve competitiveness. Such policies reconsidered the potential of various economic sectors in which Cameroon had comparative advantage. The Government sought to modernize production facilities, improve food security, and fight against the high cost of living. The objective was to increase output and areas under agricultural exploitation, develop profitable sectors with high productivity and competitive potential, strengthen agricultural extension and counselling, and develop the supply of inputs such as fertilizers and seeds (Government of Cameroon, 2009). Some of the most dynamic sectors in Cameroon are agriculture, forestry, telecommunications, and construction. An important question is whether the economy was characterized by a reallocation of factors of production from low productivity sectors (traditional sectors) to high productivity sectors (modern sectors), thereby equalising marginal productivity of labour between sectors. 
Kobou et al. (2008) found that the growth process in Cameroon did not trigger a reallocation of production factors from low productivity to high productivity sectors.

A comparison of the three main sectors suggests that the service sector dominated over the entire study period (Figure 1). Hence agriculture, in spite of being the driving force of the economy, was not the dominant component. Furthermore, there were disconnections between industry and services confirming the low level of integration at least of these two sectors which is also an indicator of the structural weakness of the economy. The share of industry increased considerably between 1976 and 1982, probably reflecting "the oil effect." The scissors-like movement between 1982 and 1991 seems to mark the passage from agriculture to industry, which lasted only for a short time. Whatever the case, this movement remains artificial. For a long time industry received substantial support, to the disadvantage of the agricultural sector. Such support and oil revenue seem to have restricted the structural transformations of this sector, as well as the possibility for the sector to make a significant contribution to long-term development. However, the declining share of agriculture and or the primary sector was persistent. It should be noted that though the agricultural sector enjoyed rapid long-term productivity growth in the late 1990s (figure 2), the value of productivity remains very low (figure 3), perhaps due to the relatively low price of agricultural goods. What then is the role of fiscal policy in driving agricultural productivity relative to the modern industrial sector?

\section{Theoretical and empirical approaches}

\subsection{Theoretical model and literature review}

Similar to the literature on international convergence (Note 4) of labour productivity, national convergence of sectoral productivity levels can also be explained from the endogenous (Note 5) growth model. Productivity convergence and productivity growth are not interchangeable. Sectoral productivity levels can converge while productivity falls or rises in one or both sectors. Nevertheless, the driving forces behind overall productivity growth would equally have an effect on sectoral productivity changes for convergence to occur. However, it should be understood that for sectoral productivity levels to converge, e.g., agriculture (AGRlp) and industry (INDlp) or service (SERlp), the ratios (AGRlp/INDlp or AGRlp/SERlp) should tend to one and this requires that agricultural productivity grows faster than the others. Thus, the sources of productivity growth performances and convergence are the same.

The usual theoretical presentation of these concepts is based on the result of the Cobb-Douglas model using two factors of production, labour and capital, and the embodied technical progress:

$$
\mathrm{Y}=\mathrm{F}(\mathrm{TFP}, \mathrm{K}, \mathrm{L})=\mathrm{TFP} \times \mathrm{K}^{\alpha} \times \mathrm{L}^{\beta}
$$

where $\mathrm{Y}$ is the production, TFP is technical progress or total factor productivity, $\mathrm{K}$ is physical capital, and $\mathrm{L}$ is labour. Taking logarithmic differences, i.e. the rate of growth, the relationship is expressed as:

$$
\Delta \mathrm{y}=\Delta \mathrm{tfp}+\alpha \Delta \mathrm{k}+\beta \Delta 1
$$

and provides the GDP growth breakdown, split between improvements in technical progress and growth of the two factors of production with $\alpha$ and $\beta$ representing the elasticities of the production factors, whose sum is equal to one, $\alpha+\beta=1$.

$$
\Delta(\mathrm{y}-1)=\Delta \mathrm{tfp}+\alpha \Delta(\mathrm{k}-1)
$$

The relationship (3) determined from (2) provides a breakdown of the change in labour productivity $\Delta(\mathrm{y}-1)$ into two effects: the effect linked to capital deepening or capital intensity $\Delta(\mathrm{k}-1)$ and the effect linked to total factors productivity $\Delta$ tfp. The multi-factor productivity concept embraces all variables that affect output for any given level of inputs. It accounts for the growth not accounted for by capital accumulation or increased inputs. The components usually included in this unexplained growth are: advances in knowledge (i.e. education and training), research, and efficiency in the allocation of resources. Thus, labour productivity is determined by the amount of available factor inputs, i.e. labour (including human capital), physical capital and intermediate inputs (Vander and Wiel, 1999) (Note 6). It is argued that adequate nourishment, health and education facilities are essential for increasing labour productivity (Corvers, 1997; Vander Wiel, 1999). Inspiring from the link between tfp and labour productivity performance, Ratts $\varnothing$ and Stokke (2003) provide econometric results and review similar cases in agriculture and industry.

Heisey (2001) concludes that investment in research and development for agricultural production are necessary for agricultural productivity growth, and in this study, government allocation in agriculture is considered as a proxy. A number of studies have also documented the relation between social spending on education and health — variants of human capital — and productivity of workers. Health can affect productivity, assuming that a 
large proportion of the working population must be in good health to function well, though the issue remains under-researched and controversial on the direction of causality between health and income (Harris, 2002). For instance, Acemoglu and Johnson established no causal effect between health and income per capita.

Chang et al (2006) introduce government taxation and infrastructure expenditure in the model proposed by Matsuyama (2002) and shows that, under proper conditions, agricultural productivity has a positive effect on growth via such spending. The government expenditure must be productive in the spirit of Barro (1991), in that the learning-by doing effect of the manufacturing sector is enhanced with the expenditure, hence generating convergence tendencies of sectoral labour productivity levels. Examples of such productive public expenditures include those in the areas of infrastructure, public education, and institutional reconstructions (Chang et al 2006) (Note 7). Lastly, the literature also suggests that free market policies or small governments with open markets that encourage foreign trade foster productivity growth (Edwards 1998). Irz and Roe (2005) point that trade liberalisation can substantially accelerate growth of an agricultural poor country through its effects on agricultural productivity while Ratts $\varnothing$ and Stokke (2003) provide a positive link between foreign spillovers (channelled through foreign trade or openness and foreign investment) in industry.

However, despite the various sources of productivity discussed above, sectoral productivity differences arise. Following the writings of Adam Smith, most economists seem to have taken it as axiomatic that productivity grows less rapidly in agriculture than in the manufacturing sector (Note 8). The dual economy model inspired by the work of Lewis (1954) typically features a distinction between a stagnant, traditional rural sector, and a dynamic modern manufacturing sector. However, other offshoots of the model that centre on the agriculture-industry interactions provide better prospects for higher rates of agricultural productivity and growth (Note 9). Thus, analyses on the interactions between agriculture and industry dwells on the literature of structural change embedded on the work of Lewis (1954) to explain productivity growth.

In Lewis model, development is viewed as absorption of labour from the low-productivity rural-agricultural sector into the high-productivity urban-industrial sector. This process should obviously lead to sector labour productivity convergence (i.e. productivity levels growing more equal) or divergence initiated by the reallocation of labour force. As workers migrate to the urban sector, average productivity in agriculture rises eventually, with the disappearance of the disguisedly unemployed labour force and the "commercialisation" of the agricultural sector and thus, the whole economy, leading to increasing agricultural real wage (Todaro, 2000). Gemmell et al. (2000) reiterate that such a situation could only be possible if productivity-enhancing advances in industrial technologies tend to spill over to agriculture. In the case of developing economies where technological advances are generally imported, this might be expected take the form of productivity improvements in industry spilling over to agriculture. To the extent that three sectors compete in factor markets, this will reinforce tendencies towards equality in labour productivity (Gemmell et al., 2000).

Ratts $\varnothing$ and Torvik (2003) use a dynamic extension model and assume learning-by-doing in industry and catching-up in agriculture to demonstrate that discrimination against the latter may reduce growth and the technological advantage of industry. Finally, since in most economies, economic growth comes from productivity growth and the latter accounts for changes in poverty better than the former (CSLS 2003), we posit that sectoral productivity growth and convergence can be a solution to the poverty crisis in agricultural economies through the spillover effect.

There is no direct link between productivity convergence and poverty. The existence or not of convergence has uncertain implications for the level of productivity in any sector. However, convergence of productivity levels would reduce poverty if the ratio of agriculture to non-agricultural productivity tended to one, which occurs when the former grows faster than the latter. Productivity growth is the main determinant of income growth (Steindel and Stiroh 2001; Catia, 2003), which explains why productivity growth reduces poverty (Note 10).

\subsection{Econometric model and data}

Based on the fact that agricultural productivity is low relative to the other sectors in Cameroon, it is hypothesised that fiscal spending which leads to improvements in agricultural productivity more than proportionately to non-agricultural productivity closes productivity gaps or creates convergence. Public expenditure and or fiscal policy should promote productivity growth and convergence via a rapid long-term agricultural productivity growth. There is no definite literature on convergence and fiscal policy but there are possible links between fiscal variables and productivity growth as discussed in the literature above. A priori, the fiscal variables should have positive coefficients mostly benefiting the agricultural sector in line with the existence of an 'advantage of backwardness' (Gerschenkron, 1952) where being relatively backward in productivity carries a potential for rapid advance (Abramovitz 1979, 1986). 
In a second model, we assume that productivity convergence can occur through technology flow from manufacturing to agriculture i.e., spillover effects (Gemmell et al. 1998; Niels-Hugo and Verner, 2006). Thus, we specify two econometric models. The first describes the link between sectoral differences in labour productivity (i.e. the convergence term) and fiscal measures. The second tests for the existence of sectoral interaction of productivity levels which provides a picture of convergence via spillovers.

Productivity is referred to as output per unit of input such as labour, land, capital, and raw materials. Total factor productivity growth is defined as output growth in relation to a weighted sum of the growth of factors of production (usually labour and capital) and represents technical progress. Labour productivity is much more closely related to potential increases in real income and living standards than total factor productivity (CSLS, 2003), and is our preferred variable in this paper.

Labour input can be measured using total employment, total hours worked, or a quality-adjusted measure of labour input. Like in the literature, we use the aggregate labour force as a proxy for labour input, although it will not capture its quality. Thus, in this paper, labour employed in the main economic sectors including agriculture, industry and service are used as labour inputs to measure productivity in the various sectors respectively.

Assessing whether the productivity gap is closing or expanding takes us to the notion of convergence as earlier mentioned. In this study, convergence in sectoral productivity level is measured in line with the objective of examining the factors that push up agricultural productivity towards the level of non-agricultural (industrial) productivity. For sectoral productivity levels to converge (e.g., agriculture and industry or and service), the ratios of agricultural productivity to either productivity in manufacturing or service should tend to one and this requires that agricultural productivity grows faster than the others.

Pertaining to the benefits of convergence, we assume that a catch-up of agricultural productivity to the level of non-agricultural productivity is a pre-condition for and has a significant impact on long-run growth, where growth is defined as the average rate of change of real per capita GDP, a proxy for increased returns. It is expected that improved growth will help to reduce poverty. In African countries, agriculture is important for growth and contributes a large proportion to GDP. Most of the poor people are dependent on the rural economy for their livelihood and the performance of the agricultural sector has far-reaching implications for food, poverty reduction, and income generation. The Lewis-Ranis-Fei approach also views development as involving the disappearance of the disguised unemployed labour force and the commercialisation of the agricultural sector and thus, the whole economy leading to a rise in agricultural real wage. This occurs with a catch-up in agricultural productivity to that of the urban-industrial sector, consequently leading to an overall rise in output or growth.

The model specification showing the relationship between fiscal variables and convergence as well as that which provides interrelationship between sector productivity levels are broadened to identify and control for other variables that may also have affected convergence or agricultural productivity during that period. For instance, outward-oriented policies should favour foreign trade and thus foster agricultural productivity in an agricultural based economy (Edwards, 1997; Irz and Roe, 2005). Openness may also encourage convergent tendencies through knowledge diffusion and competition or divergent pattern since trade advances international specialisation (Grossman and Helpman, 1991). Secondly, capital invested in a particular sector should raise the stock of capital per worker (i.e., capital intensity) leading to a rise in productivity (Vander Wiel, 1999; Roa et al., 2003). However, the ratio of work force in manufacturing to that of agriculture indicates a possibility of labour mobility between sectors.

The general models are given by the following equations, whereas a definition of the variables used in the above equations are displayed Table 2.

(1) $\mathrm{AGR}_{\mathrm{lp}} / \mathrm{IND}_{\mathrm{lp}}=\mathrm{a}+\mathrm{b}(\mathrm{OPEN})+\mathrm{c}(\mathrm{CAPAGR})+\mathrm{d}(\mathrm{CAPIND})+\mathrm{e}(\mathrm{AGR})+\mathrm{f}(\mathrm{EDU})+\mathrm{g}(\mathrm{HLT})+\mathrm{h}(\mathrm{ROAD})+$

$\mathrm{i}($ RLABOUR $)+\mathrm{k}(\mathrm{D} 86)+\mathrm{l}(\mathrm{D} 94)+\varepsilon$

(2) $A G R l p=a^{\prime}+b^{\prime}(I N D l p)+c^{\prime}\left(S^{\prime} R_{1 p}\right)+d^{\prime}(D 86)+e^{\prime}(D 94)+\varepsilon^{\prime}$

The sources of the variables as follows: Data on variables used in computing openness were obtained from the IMF's International Financial Statistics. Underlying data for the computation of labour productivity levels comes from World Bank Tables while public expenditure information is from national sources (Ministry of Economy and Finance and the National Assembly of Cameroon) and Amin (1998). Specifically, the sector shares of capital inputs were obtained from estimates of the total capital stock. The aggregate capital stock series obtained from 
the World Economic Outlook are disaggregated by share of each sector in total GDP in the initial period (Nehru and Dhareshwar, 1993; Amin, 2002).

We estimate equation (1) and equation (2) using cointegration techniques and an Error Correction Model (ECM) over the period 1969-2005. Augmented Dickey-Fuller (ADF) unit root tests were performed on the variables to determine the presence of unit root and order of integration for the series. The results led us to proceed with tests for cointegrating relationship among combinations of non-stationary series. We test for the existence of long-run relationships using the Engle-Granger two-step procedures. In this case, the equations were first estimated by Ordinary Least Squares (OLS) and unit root tests were performed on the residuals in the second stage.

For equation (2), since the series are integrated of the same order and are cointegrated, a long-run relationship exists among the variables. In such a case, the Engle-Granger representation theorem states that the appropriate form of the model is an ECM (Engle and Granger, 1987). Thus, for equation (2), a short-run dynamic model is determined and is vector autoregressive (VAR) in first differences with the lagged error term (ECT) from the cointegration equation included as an explanatory variable. It has been argued that an ECM provides a more general lag structure which does not impose an overly restrictive structure on the model (Hendry and Richard, 1990 ) and that it avoids the 'spurious' regression problem (Engle and Granger, 1987).

Equation (2) provides the dual economy model that links up the agriculture to non-agricultural sector and this determines if sectors evolve interdependently to the benefit of another. The modeling follows Gemmell et al. (1998) but we ascribe importance to exogenous events such as trade shocks and policy changes. The arguments offered to account for sectoral interrelationships are that agricultural productivity is positively related to manufacturing and service productivity both in the short-and long-run. Issues also relating to sectoral growth linkages have been addressed in the dual economy model (Gemmel et al., 2000; Niels-Hugo and Verner, 2006).

\section{Results}

In this section, we present our findings in terms of the role played by Cameroon public expenditure or fiscal policy in productivity convergence between agriculture and the manufacturing sectors respectively as well as the interrelationships between these economic sectors including the service sector.

\subsection{Labour Productivity Convergence}

Table 3 provides the co-integrating regression results that explain the convergence of agricultural and manufacturing productivity levels. The explanatory power of the models is satisfactory, accounting for about 90 percent of the variations in labour productivity convergence in Cameroon. Government spending on education, health and road infrastructure appear to favour labour productivity convergence. We found that health spending has a significant coefficient; while education spending is insignificant, which implies that public spending in the social sectors has little effect on convergence of labour productivity.Thus, it would appear that government education expenditure is inefficient or poorly targeted. Government spending on roads significantly influence productivity convergence, whereas spending on agriculture does not favour agricultural labour productivity as it reinforces inequality between agriculture and manufacturing productivity levels. There are indications that information networks such as research and extension services in agriculture which account for part of government spending in agriculture lead to stagnant technology. In sub-Saharan Africa, limited research investments and few technological breakthroughs as well as the difficulty of transferring research results to farmers due to limited resources for extension services (Heisey, 2001) may be responsible for the result.

On the other hand, outward-oriented trade policies reinforce agricultural productivity with the possibility of encouraging convergence though it appears insignificant just like the devaluation dummy. Trade enhances convergence through knowledge diffusion, increasing competition and adequate market for goods (Grossman and Helpman, 1991) and is believed to foster agricultural productivity (Irz and Roe, 2005) and thus, convergence. However, convergence reinforced by the economic factors mostly benefitting the agricultural sector is in line with several studies (Gerschenkron, 1952; Abramovitz, 1979, 1986; Martin and Mitra, 2001), which found that being relatively backward in productivity carries a potential for rapid advance.

Capital investment reinforces capital intensity (i.e. capital per worker) and has a positive effect on productivity. This result is in line with the theory of production where, productivity performance is tied to capital inputs or capital deepening (Vander Wiel, 1999). However, while capital inputs in agriculture sector effectively influence agricultural productivity and thus convergence, manufacturing capital favours divergence of productivity levels. Nevertheless, capital in manufacturing still has a role to play in the convergence of agricultural and manufacturing productivity levels. The expansion of the manufacturing sector shall be accompanied in the long-run by the absorption of more and idle (unproductive) labour from the agriculture, resulting to increased 
marginal productivity of agriculture. This can occur through technological spill-overs, i.e. mobility of ideas as discussed further below. The prediction that a growing proportion of the work force will be employed outside agriculture and average productivity in agriculture will rise faster than in non-agriculture resulting to convergence - the Lewis-Fei-Ranis model - is evident in Cameroon. As the migration of workers out of agriculture into the non-agricultural sector causes an absolute (Note 11) decline of labour in the former sector, there is a subsequent and remarkable increase in agricultural productivity, enabling the catch-up process or convergence.

\subsection{Interdependence of sectoral productivity}

Here we verify that there are sectoral linkages or dynamic sectoral interactions, i.e., the process of structural change generate spillovers in production techniques from non-agriculture to agriculture resulting to growth in agricultural productivity. The estimation results based on equation (2) that provides the long-run relationships between sectoral labour productivity levels are given below (t- ratios beneath parameters estimates).

$\log ($ AGRlp $)=-5.1+.14 \log ($ INDlp $)+.4 \log ($ SERlp $)-.31$ D $86+.16 \mathrm{D} 94$

$$
(-3.65) \quad(1.91 \quad(1.6) \quad(-5.2)
$$

$$
\overline{R^{2}}=0.66 \quad \text { F-statistics }=14.9 \quad \mathrm{DW}=1.5 \quad \mathrm{ADF}=-2.64(0.001)
$$

The results indicate the presence of interdependence of sectoral productivity. Our estimated long-run relationship indicates that improvements in labour productivity in manufacturing and services leads to higher productivity in the agricultural sector, suggesting technological spillovers and a possible convergence of sectoral productivity levels over time. The results support the neoclassical argument that higher productivity techniques in manufacturing will tend to spill-over to agriculture, given the fact that the coefficient on service activities is insignificant. Furthermore, labour productivity in agriculture does not Granger-cause productivity elsewhere in the economy but productivities in manufacturing and service activities do Granger-cause productivity growth in the agricultural sector (results available on request). However, agricultural productivity may take a long time to catch up with the non-agricultural sector productivity (especially the manufacturing sector where the gap between them remains wide (see figure 3). Only 0.02 percent of the gap is closed up each year (Note 12). The process of convergence as discussed in the neoclassical theory may therefore be a long one in Cameroon. However, we also estimated an ECM of productivity growth in agriculture to model short-run dynamics. The estimation results are (t- ratios beneath parameters estimates) are presented below.

$$
\begin{array}{ccc}
\Delta \log (\text { AGRlp })=-.01+.29 \Delta \log (\text { INDlp })-.06 \Delta \log (\text { SERlp })-.63 & \text { ECT(-1) } \\
\overline{R^{2}}=0.29 \quad \text { F- Statistics }=4.8 \quad \mathrm{DW}=1.7 & (-3.6)
\end{array}
$$

Based on diagnostic tests, the ECM appears robust. The error correction term has a coefficient less than one and significant at 1 percent with a feedback effect of 63 percent. This means that in both the short and long run, increases in manufacturing productivity level has a positive impact on agricultural productivity. Results are similar to Gemmell et al., (1998) where the dominant short-run effect is one of sectoral competition, and it is the service sector that keenly appears to compete with agriculture. The coefficient on manufacturing and services are both negative and only significant for the latter in Gemmell et al. (1998). The authors conclude that their results lend support to the commonly-held view that for much of the agricultural labour force; it is the service sector that represents the most likely alternative to agricultural employment. Our results only mildly support this view perhaps as a result of the highly-segmented labour market, where labour in agriculture cannot be employed in the service sector consisting of mostly skilled workers except in the long run, after having undergone some training.

\section{Conclusions and policy recommendations}

The aim of this paper has been to assess the role of fiscal policy and other economic factors such as capital inputs, labour mobility and openness to trade on sectoral productivity convergence and infer the poverty impact of such convergent tendencies seen as a relative gain in agricultural productivity. The empirical literature on sectoral interactions in the process of structural change is vast and seeks to explore the linkages from non-agriculture to agricultural activities and vice versa.

This paper provides evidence that intersectoral linkages promote the catch-up of agricultural productivity with industry and/or service productivity. Furthermore, the convergence process depends on fiscal and other economic factors. The models developed here are embedded in the literature of structural change, namely the 
Lewis-Ranis-Fei approach. We assume that development means absorption of labour from the low-productivity rural or agricultural sector into the high-productivity urban-industrial sector, in which case productivity levels should converge. However, we find that technology via knowledge diffusion also plays a greater role just like the actual movement of workers. Productivity convergence coming either from economic factors or indirectly via spillovers from sectoral interaction has the effect of raising output growth via a rise in agricultural productivity. One of the most important arguments is that there are possibilities of a reduction in poverty following increased production, lower prices and farm income.

Taking Cameroon as a case study, our empirical results suggest that fiscal policy partly explains the convergence of agriculture and manufacturing productivity levels. Apart from spending on education, which has an insignificant influence on convergence, perhaps due to inefficiency or poor targeting, other components of public spending such as road infrastructure, health, and agriculture also influence sectoral productivity levels. However, spending on agriculture fosters productivity divergence. This is observed as an increase in the gap between agriculture and non-agriculture through a relative gain in manufacturing productivity.

Economic fundamentals such as openness to trade play a limited role in restoring equality in the level of sectoral productivity, whereas agricultural investment capital crowds-in labour productivity convergence. In terms of dynamic sectoral interactions, increases in manufacturing and services both have a positive impact on agricultural productivity in the long run with feedback effect from manufacturing being guaranteed also in the short run. This supports the neoclassical focus on spillovers of production techniques or ideas from manufacturing to agriculture, fostering convergence in sectoral productivity levels.

The main policy recommendation is that poverty reduction in Cameroon could be achieved by government investment on social and road infrastructures. The empirical findings suggest that government spending on roads, health and - to a little extent-education have been effective, but spending on agriculture has been less so in terms of raising agricultural productivity. A second policy implication is that if a particular spending creates divergence in productivity levels as in the case of spending on agriculture and manufacturing capital, they could still in the long run, indirectly raise agricultural productivity via spillovers. Thus, Cameroon could still reduce poverty and enhance growth if spending on infrastructure such as education, health, rural roads, and agricultural equipments and research were rendered efficient and judicious. Nonetheless, adequate time is required for such measures to spur the convergence process. The nature of targeting should also ensure that the agricultural sector continues to benefit from spillovers in terms of labour productivity. Furthermore, attention should be given to interdependencies in sectoral productivity. Specifically, the farming population in the rural areas should be properly targeted to sustain growth in output and productivity. Finally, our work is only a first step in analysing productivity convergence across sectors or region. Using partial productivity indicators such as output per unit of labour only captures trends in output relative to one input and can be misleading in cases where the input mix is changing or where there are technical advances allowing increases in output for a given level of input use. A superior measure such as total factor productivity could be used in future research to overcome these problems.

\section{References}

Abramovitz M. (1986). Catching up, Forging ahead and falling behind. Journal of Economic History, 47.

Acemoglu D and Johnson S. (2007). Disease and development: The effect of life expectancy on economic growth. Journal of Political Economy, Vol. 115. http://dx.doi.org/10.1086/529000

Adam J. Akperan. (2003). Sub-Saharan Africa: External Debt, Economic Growth and Poverty Reduction. African Journal of Economic Policy, Vol. 10, No. 1.

Ahmad, N François, L P Marianna, D Pilat, Paul S. \& A. Wolfl. (2003). Comparing Growth in GDP and Labour Productivity: Measurement issues OECD. Statistics Brief, No. 7, December.

Amin A A. (1998). Cameroon's Fiscal Policy and Economic Growth. AERC Research paper, No. 85, AERC Nairobi.

Amin A A. (2002). An Examination of the Sources of Economic Growth in Cameroon's Economy. AERC Research paper no. 116, AERC Nairobi.

Barro R J. (1991). Economic Growth in a Cross Section of Countries. Quarterly Journal of Economics, 106.

Biswo N. Poudel, Krishna P. Paudel, \& David Zilberman. (2011). Agricultural Productivity Convergence: Myth or Reality? Journal of Agricultural and Applied Economics, 43, 1.

Catia Felisberto. (2003). Importance of labour productivity Growth: Portugal versus Ireland. Paper presented at the macroeconomic modelling workshop, Université de Lausanne, July. 
Centre for the Study of Living Standards. (2003). Productivity Growth and Poverty Reduction in Developing Countries. Background Paper prepared for the 2004 World Employment Report of the International Labour Organisation. CSLS Research Report No.2003-06 (Ottawa: CSLS).

Chang, J. J., B. L. Chen \& M. Hsu. (2006). Agricultural Productivity and Economic Growth: Role of Tax Revenues and Infrastructures. Southern Economic Journal, 72, No. 4, 891-914. http://dx.doi.org/10.2307/20111859

Corvers Frank. (1997). The impact of human capital on labour productivity in the manufacturing sectors of the European Union. Applied Economics, 29

Datt Gaurav \& M Ravallion. (1998). Farm productivity and Rural Poverty in India. Journal of Development Studies, Vol. 34, (4).

Department of Agriculturery DF. \& JF Richard. (1990). On the formulation of empirical models in dynamic eoconometrics, In C.W.J. Granger (ed.) Modelling economic series: Reading in econometric methodology. Clarenton Press, Oxford.

Dollar D and A Kraay. (2002). Growth is Good for the Poor. Journal of Economic Growth, Vol. 7. http://dx.doi.org/10.1023/A:1020139631000

Dorward A, Poulton C. \& Chirwa E. (2009). Markets and Dynamic (agricultural) Development. Paper presented at the ILRI AGRA Conference on, Towards Priority Actions for Market Development for African Farmers, Nairobi, 13th to 15th May.

Edwards S. (1998). Openness, productivity and Growth: What do we really know? The Economic Journal, Vol. 108, No. 447. http://dx.doi.org/10.1111/1468-0297.00293

Engle RF \& CWJ Granger. (1987). Cointegration and Error Correction: Representation, estimation and testing. Econometrica, 49.

Fan S, L X Zhang \& X B Zhang. (2002). Growth, Inequality, and Poverty in Rural China: The Role of Public Investments. Research Report 125, International Food Policy Research Institute, Washington, D.C.

Gemmell N, Tim Lioyd \& Marinan M. (2000). Agricultural Growth and Intersectoral linkages in a Developing country. Journal of Agricultural Economies, 51(3).

Government of Cameroon. (2003). The Poverty Reduction Strategy Paper. Ministry of Planning, Programming and Regional Development.

Government of Cameroon. (2009). Growth and Employment Strategy paper: Reference Framework for Government Action over the period 2010-2020. Ministry of Planning, Programming and Regional Development.

Grossman G M \& Helpman. (1991). Innovation and Growth in the Global Economy. Cambridge MA, MIT press.

Harris R G. (2002). Social Policy and Productivity Growth: What Are the Linkages. In Andrew Sharpe, Keith Banting and France St-Hilaire (Eds.), The Review of Economic Performance and Social Progress: Towards A Social Understanding of Productivity. Ottawa: Centre for the Study of Living Standards and Montreal: Institute for Research on Public Policy and distributed by McGill-Queen.s University Press. Retrieved from www.csls.ca

Heisey PW. (2001). Agricultural Research and Development (R\&D), Agricultural Productivity and Food Security. Agricultural Information Bulletin No. 765-10. Washington, D.C.: Economic Research Service, U.S.

Institut National de La Statistique. (2008). Conditions de vie des Populations et Profil de Pauvrete Au Cameroun en 2007: Rapport Principal de L'ECAM3.

Irz Xavier \& Terry Roe. (2005). Seeds of growth? Agricultural productivity and the transitional dynamics of the Ramsey model. European Review of Agricultural Economics, 32 (2):143-165. http://dx.doi.org/10.1093/eurrag/jbi007

Kobou G, Njinkeu D \& BP Fosso. (2008). The Political Economy of Cameroon's Post-Independence Growth Experience. In B. J. Ndulu, S. A. O'Connell, J.-P. Azam, R. H. Bates, A. K. Fosu, J. W. Gunning and D. Njinkeu (Eds.), The Political Economy of Economic Growth in Africa, 1960-2000, Volume 2: Country Case Studies (pp. 547-587). Cambridge: Cambridge University Press.

Lewis AW. (1954). Economic Development with Unlimited Supplies of Labour. Manchester School, 22, (May).

Mahran H A. (2000). Food Sercurity and Food Productivity in Sudan, 1970-95. African Development Review, Vol. 12, No. 2. 
Martin W \& D Mitra. (2001). Productivity Growth and Convergence in Agriculture and Manufacturing. Economic Development and Cultural Change, 49(2). http://dx.doi.org/10.1086/452509

Matsuyama K. (1992). Agricultural productivity, Compartive advantage and Economic growth. Journal of Economic theory, 58.

Nehru Vikram \& Ashok Dhareshwar. (1993). A new database on physical capital stock: Sources, methodology and results. Rivista de Analists Economico, 8(1).

Niels-Hugo Bluch \& Dorte Verner. (2006). Shared Sectoral Growth Versus the Dual Economy Model: Evidence from Côte d'Ivoire, Ghana, and Zimbabwe. African Development Review, 18(3):283-308.

Ranis G \& John C H Fei. (1961). A Theory of Economic Development. American Economic Review, Vol. L1, No. 4 (september).

Ratts $\varnothing$ J $\varnothing \mathrm{rn} \&$ HE Stokke. (2003). Learning by doing and domestic and foreign technology spillovers in Thailand: some empirical evidence. Nordic Journal of Political Economy, 29(1): 47-66.

Ratts, Jorn \& Ragnar Torvik. (2003). Interactions between Agriculture and Industry: Theoretical Analysis of the Consequences of Discriminating Agriculture in Sub-Saharan Africa. Review of Development Economics, 7(1).

Roa Someshwar, J Tang \& Weimin Wang. (2003). Canada's recent productivity records and capital accumulation. Microeconomic policy Analysis Branch, Industry, Canada.

Rostow Walt W. (1960). The stages of Economic Growth: A Non-Communist Manifesto. In Todaro M.P. (Ed.), Economic Development, Addisson-Wesley. London: Cambridg University Press, 2000.

Sachs Jeffry D \& Warner Andrew. (1995). Economic Convergence and Economic Policies. NBER working paper no. 5039 (february).

Steindel C \& Stiroh Kevin J. (2001). Productivity: What is it, and why do we care about it? Business Economics, Vol. XXXVI, No. 4 (October), 13-31.

Tabi Atemnkeng J. (2005). Fiscal policy and Sectoral Productivity Convergence in Cameroon: Implications for Poverty Reduction, May, Global Development Network. Paper presented in a Washington Conference at the IMF

Thirtle C, Lin L. \& J Piesse. (2003). The Impact of Research-Led Agricultural Productivity Growth on Poverty Reduction in Africa, Asia and Latin America. World Development, Vol. 31, No. 12. http://dx.doi.org/10.1016/j.worlddev.2003.07.001

Todaro P Michael. (2002). Economic Development. NewYork University, Addison-Wesley.

Vander Wiel HP. (1999). Sectoral labour productivity Growth: A growth accounting analysis of Dutch industries, 1973-1995. CPB no. 158, Netherlands Bureau for Economic policy Analysis, The Hague.

World Bank. (2008). World Development Report 2008: Agriculture for Development. Washington, DC: The World Bank.

\section{Notes}

Note 1. Steindel and Stiroh (2001) and Catia (2003) assert that the rate of labour productivity growth can have a large effect on real output and living standards. US labour productivity growth, measured as GDP per hour worked, has been shown to rise faster than that of some large European Union countries and this was accompanied by a relatively high US GDP per capita in comparative terms (Ahmad et al., 2003).

Note 2. Several arguments have been advanced as to why countries in which most of labour works agriculture remain largely food insecure and poor. One argument is that agricultural productivity in sub-Saharan Africa is low and farmers face low-productivity traps. Dorward et al. (2009) note that unstable food prices lead to low producer investment and consumers lock in to low-productivity food crops, which consequently lead to low agricultural productivity. Low productivity leads to low and vulnerable real incomes which in turn lead to low demand for non-agricultural goods and services. Agriculture has failed to get Africa out of poverty, and today many countries are experiencing low agricultural growth, rapid population growth, weak foreign exchange earnings, and high transaction costs (World Bank, 2008).

Note 3. Analysis by the National Statistical Office based on the most recent household survey (2007) indicates that the overall incidence of poverty is still around 40 percent, about the same level as in 2001. In Cameroon, the 2007 level of poverty remains higher for those involved in agriculture (56\%) relative to the National rate of $39 \%$ 
and $31.7 \%$ in non-agriculture with the industrial sector poverty rate of $27.6 \%$ (Institut National de La Statistique, 2008).These observations raise some interesting evaluative question in terms of pro-poor growth in Cameroon.

Note 4. Empirical tests of convergence hypothesis are mostly concerned with regional or cross country convergence in productivity level of a particular sector (see Biswo et al 2011 for a review). Intersectoral linkages and convergence between sector productivity levels has featured less prominently in theoretical models. For convergence at the national level, agricultural economies like Cameroon, where the low-productivity agricultural sector can benefit from higher productivity techniques in the manufacturing sector through spillovers imported from advanced countries.

Note 5. Endogenous growth models discard the neoclassical assumption of diminishing returns to scale in the aggregate production function and frequently focus on the role of externalities such as human capital in reinforcing the rate of return on capital investment (Todaro, 2000).

Note 6. Several others also emphasised the role of physical capital accumulation as it provides more capital per unit of labour input (i.e., it strengthens capital deepening) including human capital or skills acquired in training and information and communication technologies in creating sectoral/regional differences in productivity levels or growth especially when inter-industry capital intensity persist (Grossman and Helpman, 1991; Roa et al., 2003).

Note 7. Mahran (2000) states that, policies to improve on agricultural productivity should be reinforced by efforts to improve infrastructure, including health and education to pave the way for a positive supply response.

Note 8. For instance, Matsuyama (1992) and Sachs and Warner (1995) conclude that countries with large agricultural sectors face diminished growth prospects.

Note 9. Many developing countries have adopted policies that promote industry over agriculture. According to Bluch and Verner (1999), Martin and Mitra (1999) and Ratts $\varnothing$ and Torvik (2003), such measures are not optimal and may reduce the growth of the economy.

Note 10. There is also a huge literature on the role of the agricultural sector and agricultural productivity in reducing poverty, see for instance, Datt and Ravallion (1998), Fan et al. (2002) and Thirtle, Lin and Piesse (2003).

Note 11. It should be noted that the ratio of work force in manufacturing to agriculture is slightly upward trending over the period even though the relative share of labour in agriculture has been constant. The former indicates an absolute decline of labour in agriculture.

Note 12. The average growth rate of the ratio of AGRlp to INDlp is $-.4 \%$ whereas for the technology gap (INDlp/AGRlp), it is 3\% over the period of study. Following Ratts $\varnothing$ and Torvik (2003), productivity growth in agriculture increases by a multiple per unit rise in the technology gap. In our long-run equation, any rise in manufacturing productivity by $1 \%$ initiates a $.14 \%$ rise in agricultural productivity. Thus, overall, the ratio, AGRlp/INDlp will grow annually at $0.14(3)-0.4$ or $0.02 \%$.

Table 1. Public spending on key social sectors (\% total spending)

\begin{tabular}{|l|l|l|l|l|l|l|l|l|l|l|}
\hline & & & & & & & & & & \\
\hline
\end{tabular}

Source: The Cameroon Ministry of the Economy, Planning and Regional Development. 
Table 2. Definition of variables used in the models

\begin{tabular}{|l|l|}
\hline $\mathrm{AGR}_{\mathrm{lp}} / \mathrm{IND}_{\mathrm{lp}}$ & $\begin{array}{l}\text { Productivity gaps between agriculture and manufacturing or industry (.i.e., } \\
\text { convergence) }\end{array}$ \\
\hline CAPAGR/CAPIND & Capital inputs in agriculture or industry (1987 prices) \\
\hline LABAGR & Growth rate of labour force in agriculture \\
\hline Rlabour & Ratio of labour in manufacturing to agriculture sector \\
\hline OPEN & Openness measured as exports + imports to GDP ratio \\
\hline $\mathrm{D}_{86}$ & Dummy for the crisis period (1970 to $1985=0,1986-2005=1)$ \\
\hline $\mathrm{D}_{94}$ & Dummy for the devaluation period (1970 to $1993=0,1994-2005=1)$ \\
\hline $\mathrm{AGR}_{\mathrm{lp}}$ & Absolute level of labour productivity in agriculture $(1987$ prices) \\
\hline $\mathrm{IND}_{\mathrm{lp}}$ & Absolute level of labour productivity in manufacturing (1987 prices) \\
\hline $\mathrm{SER}_{\mathrm{lp}}$ & Absolute level of labour productivity in service sector (1987 prices) \\
\hline EDU, HLT, AGR, ROAD, & $\begin{array}{l}\text { Share of government expenditures in GDP on education, health, agriculture, } \\
\text { and road infrastructure. }\end{array}$ \\
\hline
\end{tabular}

Table 3. Regression Results of the Convergence Model

Dependent Variable: $\mathrm{AGR}_{\mathrm{lp}} / \mathrm{IND}_{\mathrm{lp}}$ (Ratio of agriculture to manufacturing productivity)

\begin{tabular}{|c|c|c|c|}
\hline Models & 1 & 2 & 3 \\
\hline \multirow[t]{2}{*}{ Constant } & -1.5 & -1.4 & -1.5 \\
\hline & $(-1.72)^{\mathrm{c}}$ & $(-1.43)$ & $(-1.68)$ \\
\hline \multirow[t]{2}{*}{$\log (\mathrm{OPEN})$} & 0.04 & & \\
\hline & $(0.27)$ & & \\
\hline \multirow[t]{2}{*}{ Log(CAPAGR) } & 0.63 & 0.65 & 0.63 \\
\hline & $(5.10)^{\mathrm{a}}$ & $(7.68)^{\mathrm{a}}$ & $(4.96)^{\mathrm{a}}$ \\
\hline \multirow[t]{2}{*}{ Log(CAPIND) } & -0.77 & -0.78 & -0.77 \\
\hline & $(-7.17)^{\mathrm{a}}$ & $(-10.26)^{a}$ & $(-7.0)^{\mathrm{a}}$ \\
\hline \multirow[t]{2}{*}{$\log ($ EDU $)$} & 0.05 & 0.05 & 0.05 \\
\hline & $(0.771)$ & $(0.708)$ & $(0.585)$ \\
\hline \multirow[t]{2}{*}{$\log (\mathrm{HLT})$} & 0.29 & 0.34 & 0.29 \\
\hline & $(1.77)^{\mathrm{c}}$ & $(1.80)^{\mathrm{c}}$ & \begin{tabular}{|l|}
$(1.68)$ \\
\end{tabular} \\
\hline \multirow[t]{2}{*}{$\log (\mathrm{AGR})$} & -0.20 & -0.20 & -0.20 \\
\hline & $(-2.03)^{b}$ & $(-2.01)^{b}$ & $(-1.75)^{\mathrm{c}}$ \\
\hline \multirow{2}{*}{$\log (\mathrm{ROAD})$} & 0.06 & \begin{tabular}{|l|}
0.07 \\
\end{tabular} & 0.06 \\
\hline & $(1.83)^{\mathrm{b}}$ & $(1.99)^{b}$ & $(1.76)^{b}$ \\
\hline \multirow[t]{2}{*}{ RLABOUR } & 9.8 & 10.2 & 9.9 \\
\hline & $(2.40)^{\mathrm{b}}$ & $(2.64)^{b}$ & $(2.35)^{\mathrm{b}}$ \\
\hline \multirow[t]{2}{*}{ D94 } & & 0.04 & \\
\hline & & $(0.539)$ & \\
\hline \multirow[t]{2}{*}{ D86 } & & & 0.01 \\
\hline & & & $(0.143)$ \\
\hline $\begin{array}{l}\text { Unit Root Test on ECT } \\
\text { (ADF) }\end{array}$ & $-2.64^{\mathrm{a}}$ & $-2.64^{\mathrm{a}}$ & $-2.64^{\mathrm{a}}$ \\
\hline $\mathrm{R}^{2}$ Adjusted & 0.91 & 0.91 & 0.90 \\
\hline F-STAT & 38.12 & 38.5 & 32.3 \\
\hline D-W & 1.68 & 1.86 & 1.71 \\
\hline
\end{tabular}


Note: $\mathrm{a}, \mathrm{b}$ and $\mathrm{c}$ indicate levels of significance at $1 \%, 5 \%$ and $10 \%$ respectively and t-ratios are in parenthesis. Source: Authors' estimations.

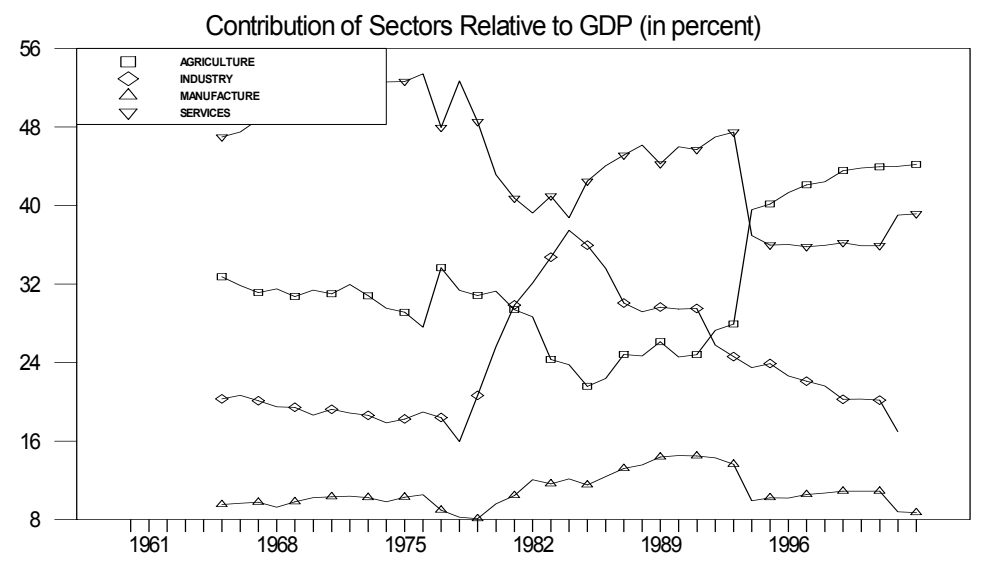

Figure 1. Contribution of sectors in GDP

Source: Koubou et al (2008)

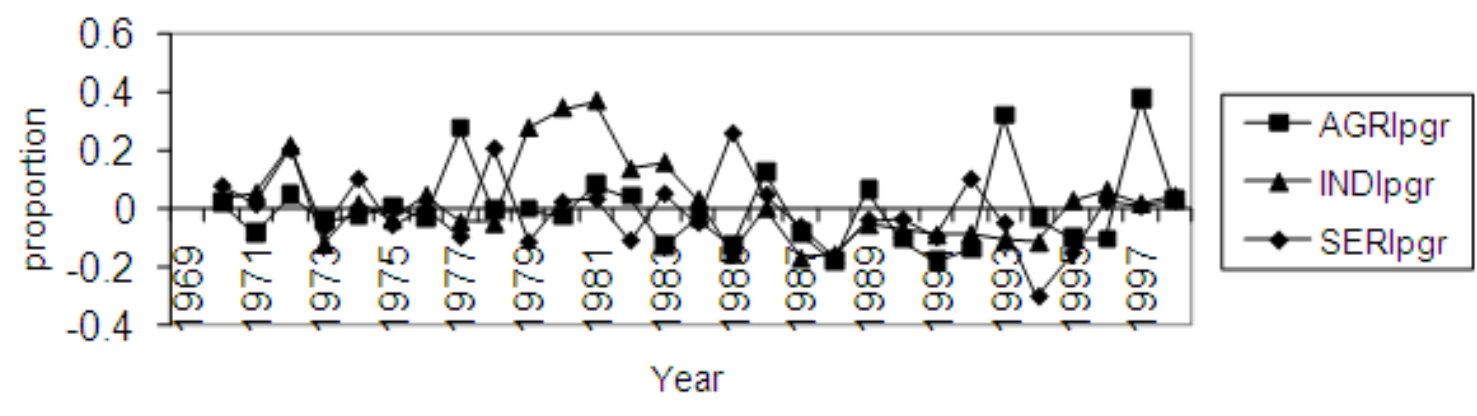

Figure 2. Sectoral productivity Growth Rates

Source: Tabi (2005)

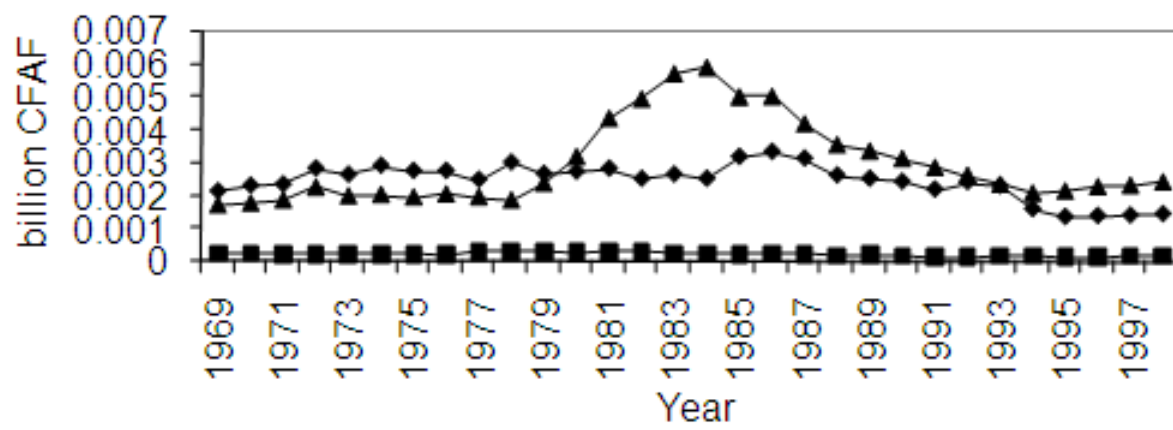

Figure 3. Evolution of sectoral productivity levels

Source: Tabi (2005) 